\title{
Re-Reading Folly: Rabelais's Praise of Triboullet
}

CAMILLA J. NILLES

Summary: Rabelais's praise of Triboullet differs from earlier works on folly by using the fool's differing perspective to conduct its search for authentic meaning. The descriptions of the sage mondain and the divine fool initiate the process, establishing folly and wisdom as relative terms, whose meaning is determined by shifting perspectives. In the praise of Triboullet, Pantagruel's and Panurge's differing referential frames are embodied by parallel columns of epithets. While each list's internal coherence and its relation to the other is guaranteed by analogy, they use difference to generate new epithets, constantly moving from the known to the unknown. Finally, the text's unconventional configuration forces readers as well to adopt a detached perspective, actively engaging them in the pursuit of meaning.

\section{$\mathrm{R}$}

abelais's Tiers Livre recounts Panurge's search for an unequivocal response to the question of whether or not he should marry. In a lengthy series of consultations, he interrogates all the traditional authorities to no avail. At the end of the book there remains one untried solution, one last hope, one final oracle. The quest culminates with the pronouncement delivered by the renowned fool Triboullet, who paradoxically displaces all established modes of knowledge to become the ultimate source of meaning. The fool's privileged position is warranted in part by an ongoing tradition that attributed to him special powers, in part by the praise of folly that anticipates by eight chapters Triboullet's climactic appearance. The present essay investigates how Rabelais's praise of folly appropriates both the existing figure of the fool and the dynamic process that brought him into being. As a result, his encomium becomes at once 
an effort to signify the fool, a performance of the behavior it exalts and an induction into the fool's way of knowing.

The fool is a common figure in the Middle Ages and the Renaissance. ${ }^{1}$ There he is condemned to live on society's fringes, excluded from the collective experience by his aberrant behavior. His marginal position, however, affords him a unique perspective on human activity. Only he can maintain the detachment necessary to an objective viewpoint. Alone able to see the truth, the fool is also alone able to speak it. His innocence, his lack of artifice, inhibition or constraint all qualify him to be a perfect conduit, to receive and transmit unmediated truth. So flawless is the fool's representation of reality, that Sebastian Brant likens him to a mirror. The opening verses of his Narrenschiff (1494) invite readers to see reflected in the fools' myriad countenances their own foolish ways:

For fools a mirror shall it be,

Where each his counterfeit may see.

His proper value each would know,

The glass of fools the truth may show. ${ }^{2}$

Yet not all fools are as lucid as Brant's. The alienation that gives the fool critical distance also affects his judgment. He interprets reality within the referential frame provided by his own folly. Since folly, in turn, is defined as a difference, as a deviation from conventional modes of thought and conduct, the fool's perspective is oppositional. He questions the norm from which he is excluded, presents alternative realities, multiplies possible meanings. Nowhere is this more apparent than in the Moriae Encomium, where Erasmus makes Folly the champion of her own cause. Her folly grants her the privileged status of truth-teller while at the same time giving her the right to speak foolishly, that is, at variance with accepted truth, or falsely. She creates confusion: opposites unite, praise and opprobrium are redistributed in strange ways, folly and wisdom are no longer distinguishable. Now Folly's truth is equivocal, demanding further interpretation, drawing the reader into the search for meaning. ${ }^{3}$

The principle of difference that governs the fool's relation to society also articulates the history of his development in literature. The late Middle Ages identified folly with the forces of absolute evil - the diabolical, bestial element that had insinuated itself into the human condition at the fall. Like 
Brant's mirror, the image of the fool served to remind readers of their folly and encourage them to abandon their foolish ways to become worthy of salvation. ${ }^{4}$ The Renaissance adopted medieval notion of folly, but cast them in a new light. In true humanist fashion, Erasmus reduces folly to human scale and makes it relative to other human functions, among them reason and the activities it governs. Rather than an obstacle to knowing, folly becomes an instrument of self-reflection, a means of self-knowledge. Just as perspective determines the fool's way of looking at the world, so it generates the fool's changing meanings. Each successive fool originates in an existing tradition but deviates from it, involved in a continuous process of assimilation and transformation, of interpretation and response, of reading and rewriting.

\section{II}

Rabelais's Tiers Livre is affiliated with the Praise of Folly in much the same way. Scholars have long agreed that the Tiers Livre drew its inspiration from Erasmian humanism and most particularly from the Moriae Encomium. ${ }^{5}$ Rabelais himself did not hesitate to acknowledge his indebtedness. Writing to Erasmus in 1532, Rabelais metaphorically addresses him as his own "mother and father. ${ }^{6}$ When read in the light of Gargantua's famous letter to his son, where Rabelais describes his conception of father-son relationships, the filial metaphor is significant. The son derives from the father, whose image he perpetuates in a new, rejuvenated form. In similar fashion, Rabelais's praise of folly reproduces the content and spirit of the Moriae Encomium butrenews it by transferring the fool's differing perspective to the textual surface. There it orders the repeated attempts to signify the fool and governs the inquiry into his true meaning, giving the praise both the dynamism and the indeterminacy that have continuously characterized the fool's evolution.

Rabelais's praise of folly extends over two chapters and provides two different, contrasting descriptions of the fool. The divine fool, whose insight Pantagruel praises in chapter 37, is not to be confused with Triboullet, the earthy, material fool jointly celebrated by the giant and his friend in chapter 38 . Both fools find their predecessors in Erasmus, but there too they remain two distinct forms of folly. The divine fool appears only in the last pages of the Praise and is described in a tone unlike either the gently mocking irony of the first part of the Praise or the biting satire of the second part. In fact, the divine fool, who dates to the early Christian era, descends from a tradition quite different from the material fool's popular origins. In his letters to the Corinthians, 
St. Paul describes the fool-in-Christ, who disregards worldly pleasure and material goods to devote himself instead to the eternal life of the spirit - in his foolishness transcending all human understanding.

Rabelais describes the divine fool by juxtaposing him to the worldly-wise fool, making explicit the oppositional relation of the fool to the norm and recreating within the text the fool's differing perspective. As the divine fool and the worldly-wise fool confront one another, each provides a new way of seeing and interpreting its counterpart. First, the worldly-wise fool:

[C]elluy qui de près reguarde à ses affaires privez et domesticques, qui est vigilant et attentif au gouvernement de sa maison, duquel l'esprit n'est poinct esguaré, qui ne pert occasion quelconque de acquerir et amasser biens et richesses, qui cautement sçayt obvier es inconveniens de paoüerté, vous appellez saige mondain, quoy que fat soit il en l'estimation des Intelligences coelestes (1: 558).

For a fool, the portrait is a remarkably sober one: no silliness, no exaggeration, no obvious signs of folly. On the contrary, the adverbs and adjectives stress the prudence, caution, foresight and care with which the sage mondain conducts his affairs. Apart from the final concession ("quoy que fat soit il en l'estimation des Intelligences coelestes"), his folly would hardly be apparent. Inter- and intratextual reference points, however, provide a context in which to situate the sage mondain and appreciate his relative worth. The Praise of Folly has already identified this species of fool. Although, like Moria's other fools, he is hopelessly mired in materialism, he insists upon taking himself seriously, refusing to allow his life to be governed by pleasure, disdaining the company of his fellows and even rejecting the title of fool. ${ }^{7}$ The description of the divine fool that immediately follows furnishes yet another perspective on the sage mondain, retrospectively giving him meaning:

[A]insi faut il, pour davant icelles [(les Intelligences coelestes)] saige estre, je dis sage et praesage par aspiration divine et apte à recepvoir benefice de divination, se oublier soymesmes, issir hors de soymesmes, vuider ses sens de toute terrienne affection, purger son esprit de toute humaine sollicitude et mettre tout en non chaloir. Ce que vulguairement est imputé à follie (1: 558).

When seen in the light of the divine fool's sublime indifference, the sage mondain's material preoccupations appear trivial, the limitations of his narrow existence become glaringly obvious.

At the same time, the divine fool only becomes meaningful in relation to 
the worldly-wise fool. Endowed with a wisdom beyond human understanding, the divine fool is indescribable in mortal terms. His perfection can only be signified through negative affirmations, by relating him to the worldly-wise fool, but in oppositional terms. When Rabelais evokes the divine fool, he does so by enumerating the human passions and pleasures in which he takes no interest, by describing the vices from which he is free, by ridding him of all human concerns. While the worldly-wise fool is defined by his possessions and acquisitions, the verbs describing the divine fool's conduct all suggest refusal, emptying, purging, oblivion, departure. All content is removed from the divine fool to leave a vacant, empty center, once more reducing him to a nothing. Now, denied even the encumbrance of a self ("se oublier soymesmes, issir hors de soysmesmes"), the fool ascends to a state of spiritual purity that brings him into direct contact with the Deity, that makes him "apte a recepvoir benefice de divination," enabling him to receive the word of God, to be filled at last with absolute meaning.

But the promise of a perfect signifier is not kept. As Rabelais's text clearly demonstrates, the divine fool's meaning changes according to the perspective from which he is viewed. Although in the eyes of the intelligences coelestes his conduct is "sage et praesage," it is "imputé à follie" by le vulguaire, just as, inversely, the worldly-wise fool is judged "saige" from a pragmatic, human standpoint, while he is "fat...en l'estimation des Intelligences coelestes." To be sure, the intelligences coelestes are in a better position than le vulguaire to decide what most nearly approaches divine perfection. But it is their superior, celestial (and essentially "inhuman") vantage point which enables them to do so. What Rabelais's paradox makes pointedly clear is that folly and wisdom are relative terms, their meaning determined by changing perspectives and by shifting contexts.

The praise of the divine fool remains inconclusive. Neither the worldlywise fool nor the divine fool is a perfect fool. Each represents only one facet of the human condition and each possesses only a limited form of knowledge. The worldly-wise fool's understanding is clearly impaired by the gross materialism that prevents him from raising his sights to spiritual matters. Conversely, the otherworldly wisdom of the divine fool so far surpasses his human condition that he is unqualified to deal with the material concerns of daily existence. As his emptiness suggests, the divine fool is wanting. The plenitude to which he aspires is not accessible to him in his mortal state and must remain an object of unsatisfied desire for the rest of his material life.

Within the narrative structure, the praise of the divine fool is gratuitous. Pantagruel presumably introduces him to encourage Panurge to take counsel 
from a fool. But the divine fool is of no help in explaining why Panurge should consult Triboullet, to whom he bears no resemblance, either as he is conjured up by Pantagruel and Panurge in chapter 38 or as he later appears in chapter 45. Nor does the divine fool play any further role in determining Panurge's fate. Surely Pantagruel, in holding him up for Panurge's admiration, had no illusions that his friend would consult the divine fool on anything as banal as his marriage plans.

The praise of the divine fool holds forth the promise of a definitive answer to Panurge's dilemma, while at the same time deferring the moment of resolution and stalling narrative progress towards that end. It multiplies possibilities rather than reducing them to univocity, introducing dialogue between different forms of folly and setting in motion the shifting perspectives that will articulate Triboullet's praise in the following chapter. There, rather than attempt to resolve the differences between the divine fool and the worldlywise one, Rabelais brings forth yet another species of fool. His redoubled efforts to signify the fool's virtues, recreate within the text the successive reprisings of folly that took place throughout the Middle Ages and Renaissance. Like the fool's own history, Rabelais's image of folly evolves through a series of connections and confrontations that remain open-ended - not to leave his readers, like Panurge, immobile before an impossible choice, but to draw them into the pursuit of meaning in which it is itself engaged.

\section{III}

Triboullet, whom Pantagruel and Panurge jointly celebrate in chapter 38, embodies a form of folly quite different from the divine fool's Christian asceticism. Court jester to François I, he represents an institution that gave official recognition to the myriad human forms folly had taken in the popular imagination. To praise him, Pantagruel and Panurge produce a roster that embraces the entire spectrum of human activity. Recreating the varied parade of fools who marched along the drift from the Middle Ages to the Renaissance, it extends from the foolish wiseman, lost in futile contemplation of life's mysteries, to the grasping material fool, vainly pursuing sensual pleasure and earthly goods. Yet, while Pantagruel and Panurge's praise echoes traditional notions of folly, it once again gives them a dramatically different form.

The most obvious formal difference lies in the praise of Triboullet's novel configuration. Pantagruel and Panurge's encomium takes the form of two discrete columns of epithets running down either side of the page. The praise's 
visual presence immediately suggests divergence, lack of consensus, reproducing the tension inherent to folly itself and positing meaning in difference. Not surprisingly, a scanning of the lists reveals two unique, differing images of the fool. On the left side of the page, Pantagruel's list embodies one extreme of folly. Erudite and abstract, it draws on his vast humanist education. On the opposite side of the page, Panurge's list shows a very different bias. $\mathrm{He}$ is instead inspired by the instinctual drives of self-love and materialistic hedonism which have consistently governed his behavior. His earthy and concrete epithets evoke material comforts, sensual pleasure and agreeable pastimes.

Pantagruel's and Panurge's praises are each consistent with their respective author's system of reference, each drawing on his particular tastes, education and ideology. Once more, the meaning given to folly is relative, determined by the perspective of the praiser. The giant and his friend can each provide a limited understanding of the fool but neither can alone signify him completely. The number of fools, the Bible tells us, is infinite. Now Pantagruel's and Panurge's lists, each offering its own unique, differing interpretation of the same phenomenon, suggest that the meanings to be ascribed to the fool are proportionate to his number.

A second formal change in Rabelais's presentation of the fool further multiplies the possible meanings of folly. Differently from Erasmus, Rabelais gives his praise the form of a blason, moreover, a blason whose own unusual structure represents a radical departure from tradition. After its initial bifurcation into two distinct columns, the blason continues to dissolve into a series of descriptive phrases, each limited to the ever-present " $F$.," paired with an everchanging array of qualifiers. The phrases, undetermined by either conjunctions or predicates, are aligned vertically on the page in a highly unstable paratactic arrangement. Unconjugated, unmotivated, they are all equally valid, all potentially interchangeable, their advancement subject to truncation or prolongation at any given moment. The blason's repeated efforts to name its object, it has been argued, arise from a desire to seize, grasp or comprehend that object, to go beyond its surface appearance and to know its eternal essence, to make it lasting and absolute. ${ }^{8}$ In that case, the blason's "louenge" is, as Thomas Sebillet first characterized it in 1548, destined to be "perpetuele" — forever seeking plenitude in the scattered shards of the object it has shattered. Rabelais's choice of the blason suggests that continuity, that sense are to be found not in the completed whole, but in the blason's multiple, renewed approaches to it.

The lists are prevented from collapsing into pure contingency by the principle of analogy, which, as François Rigolot has shown, ${ }^{10}$ is the lists' 
generating force on both the semantic and phonic level. At times strings of epithets are governed by a common semantic theme, for example falconry in Panurge's list:
F. niais
F. passagier
F. branchier
F. aguard
F. gentil
F. maillé
F. pillart
F. revenu de queue 11

Each new qualifier derives from the one which precedes it, like its predecessor naming one more category of bird of prey. Yet, while it shares the same semantic field, it possesses entirely new phonic features. On the semantic level it recalls the past and assures the list's coherence while on the formal level it gains autonomy by introducing change and innovation, giving the list vitality and dynamism.

Phonic analogy plays an equally important role in the generation of the lists. The transition between items may take place by means of formal associations alone, without regard to the items' meaning:
F. hyperbolicque
F. antonomaticque
F. allegoricque
F. tropologicque
F. pléonasmicque

"Hyperbolicque" calls forth "antonomaticque," which shares with it the same formal ending, [-ik], and the same semantic field, rhetoric. "Antonomaticque" generates "allegoricque" according to formal analogy alone, however, since "allegoricque" introduces an entirely new semantic field, hermeneutics. "Tropologicque" follows "allegoricque" according to the same principles which produced "antonomaticque" from "hyperbolicque" but "pléonasmicque," which reverts to the semantic field of rhetoric, is again generated by formal analogy alone. Here the signifier devoid of meaning plays as vital a role in perpetuating the lists as does meaning itself. The lists are renewed by giving new forms to old meanings or by filling old forms with new meanings.

The fool can never be fully signified through the use of analogy. Each resemblance calls forth another in a potentially endless succession, advancing 
only through accumulation, adding new analogies without ever arriving at a synthetic, unified whole. ${ }^{12}$ Yet Rabelais's lists clearly demonstrate that within a field of endeavor thus circumscribed, analogy exerts a dynamic force. It does so by looking at things in differing ways. On the one hand, it finds likeness in difference to guarantee order and continuity among an endless number of heterogeneous elements; it assures that the past will be recalled, transformed and assimilated into the present. On the other hand, analogy exploits the dissimilarity existing even between nearly-identical objects, using difference to generate new names and new meanings for the fool, extending towards the future in an ever proliferating and virtually inexhaustible sequence of possibilities. To be human, Moria has shown us, is "to know nothing truly," or, obversely, always to know things imperfectly. Here, on a limited, human scale, analogy becomes a means of organizing knowledge and of moving from the known to the unknown, actively involved in the vital if endless pursuit of meaning.

Analogy plays an identical role in governing the relation between Pantagruel and Panurge's lists. As François Rigolot has shown, Panurge's list repeatedly addresses itself to Pantagruel's list. ${ }^{13}$ Each time he draws inspiration from one of the giant's epithets, Panurge changes it according to the same principles which guaranteed the internal coherence and vitality of the individual lists, using phonic and/or semantic analogy to produce new forms or new meanings. In some instances Panurge echoes the giant's praise without greatly altering either its sense or its form: "jovial" becomes "joyeulx et folastrant," "abrevié" becomes "abreviateur." At other times, Panurge takes the opposite approach, reversing the meaning of Pantagruel's epithet and introducing a new phonic structure: "celeste" becomes "terrien." Most of the time, Panurge retains some of the formal features of Pantagruel's epithet while giving it a new meaning. As suggested by the last example, Panurge's conversions are all deflationary in nature: "rusticque" becomes "de rustrie," "redoubté" becomes "radotant," "total" becomes the obscene "cotal."

Panurge generates his praise by reading and rewriting Pantagruel's, revealing the underpinnings of the blason's own genesis, thematizing the process by which Rabelais's work is derived from Erasmus's or Erasmus's from Brant's. Yet, while Panurge takes meaning from the giant's list, he also gives it meaning. With each exchange he removes the giant's qualifier from its context and places it within his own frame of reference, where it is distorted and debased. Panurge's incongruous imitation casts Pantagruel's epithets in a new light and calls into question the referential system to which they belong. In the end, it would be difficult to decide who is the greater fool: Panurge, who 
plays the clown to the wise, humanist prince or Pantagruel, who condescendingly indulges his foolish friend by singing with him Triboullet's praises and unwittingly becomes Panurge's dupe. ${ }^{14}$

As was true for the Moriae Encomium, the divergent, contradictory images of folly presented by the blason of Triboullet demand that readers actively engage the text to discover its meaning. Now, however, their efforts are further frustrated by a text whose highly unusual format seems intentionally designed to prevent a normal, conventional reading. How, in fact, should the reader respond to a text that is so unlike the ordinary printed page? The two columns of epithets deliver a visual impact whose force is difficult to resist. Displayed on the page as two opposing poles, they appear to be two selfcontained, mutually exclusive units. Because the space separating the items within each list is smaller than the space that must be bridged to move from the first list to the second, the eye is drawn downward. The downward attraction gains force from the fact that the association of ideas and sounds is more obvious on the vertical axis than on the horizontal one.

Were the two lists to be presented orally, however, the two voices would have to alternate: Pantagruel's noble qualifier would be countered by Panurge's less edifying one, which would, in turn, be reversed by Pantagruel's exalted word of praise. Readers are therefore justified in scanning the page in the traditional fashion: from left to right and back to the left again.

Neither method of reading is complete in itself: the first ignores the reflexive and mediative role played by Panurge's list while the second prevents the reader from appreciating the internal coherence and evolution of each list. The novel configuration of Rabelais's text obliges readers to abandon traditional modes of reading and to adopt a new reading strategy. They must resist the attractions of either a vertical or a horizontal reading alone. They must distance themselves, modelling their detachment on that of Panurge, who, in taking a stance relative to Pantagruel's list, merely imitates the strategy adopted by Rabelais in relation to Erasmus, by Erasmus in relation to Brant or, more generally, by the fool vis-à-vis conventional notions of wisdom.

The detached position into which Rabelais artfully maneuvers his readers has been invested with similar strategic importance by contemporary reception theorists. To paraphrase Wolfgang Iser: the text offers a variety of perspectives, all alternatively occupied by the reader at different points in the reading process. The meaning of the text (the production of the aesthetic object) is the place where all its textual perspectives converge. It can only be brought into focus, actuated or realized if it is visualized from a standpoint that is prestructured 
by the text. Only once they have taken the position prepared for them by the text will readers be able to engage the text, set in motion its multiple perspectives, fill in its gaps, participate in the creation of meaning. ${ }^{15}$

Rabelais's readers, too, must rid themselves of preconceptions, abandon a purely linear reading strategy, remove themselves to a point where they can perceive the interplay of formal and semantic structures on both the vertical and horizontal axes, relate their multiple views, formulate a coherent image of folly. Yet, as Panurge's example clearly demonstrates, the act of reading transforms and deforms its object at the same time. In Iser's words: "In this respect the literary text avails itself of a mechanism that regulates perception in general, for what is observed changes when it is observed - in accordance with the particular expectations of the observer" (Act 98). Reading multiplies meanings rather than reducing them to univocity. Just as the repeated acts of rewriting folly are inexhaustible, so too are the acts of reading them. Yet, Iser explains, "it is this very inexhaustibility that forces ... [the reader] to make his decision." ${ }^{16}$ Where the potential for meaning is unlimited, any choice is valid, but all are grounded in contingency and all infinitely subject to renewal.

In reading the blason of Triboullet, the reader is drawn into the pursuit of meaning, engaged in a quest similar to the one undertaken by Panurge in search of an unequivocal answer. Paradoxically, the blason, with its proliferation of perspectives denies the possibility of the single, immutable image whose features it had set out to establish. In similar fashion, Triboullet, once he is finally consulted, refuses to give the unequivocal answerdemanded of him and instead hands Panurge the bottle that inspires the Quart Livre's voyage of discovery in search of the Dive Bouteille. Absolute meaning is replaced by a series of relative, analogical patterns, changing with the perspective from which they are viewed and the shifting contexts that reflect and transform them. Nor is meaning to be found in a single, inalterable truth but in the creative process of discovery, in that dynamic and progressive movement which exists in perennial anticipation of the moment of fullness and completion.

Arlington, Virginia, USA

\section{Notes}

1. The history of the fool in the Middle Ages and the Renaissance has been amply documented. See Charles Béné, “"Folie' et 'sagesse' dans la littérature du XVI' siècle," Studi Francesi, 67 (1979): 1-14; Elizabeth Chesney, "The.Theme of Folly in Rabelais and Ariosto," Journal of Medieval and Renaissance Studies, 7.1 (1977): 67-93; Gérard Defaux, "Sagesse et folie d’Érasme à Molière," Modern Language Notes, 91.4 (1976): 655-71; Lillian Feder, 
Madness in Literature (Princeton: Princeton University Press, 1980), 98-146; Folie et déraison à la Renaissance, Travaux de l'Institut pour l'étude de la Renaissance et de l'Humanisme 5 (Bruxelles: Éditions de l'Université de Bruxelles, 1976); Michel Foucault, Histoire de la folie à l'âge classique (Paris: Plon, 1961) 13-55. Robert Klein, "Le Thème du fou et l'ironie humaniste," Umanesimo e Ermeneutica, Archivio di Filosofia 3 (1963): 11-25; Joël Lefebvre, Les Fols et la folie (Paris: Klincksieck, 1968); Maurice Lever, Le Sceptre et la marotte (Paris: Fayard, 1983); Barbara Swain, Fools and Folly During the Middle Ages and the Renaissance (New York: Columbia University Press, 1932); Enid Welsford, The Fool: His Social and Literary History (1935; Gloucester, Mass.: Peter Smith, 1966). In addition, Mikhail Bakhtin's chapter, "Popular-Festive Forms and Images in Rabelais" (Rabelais and His World, trans. Helene Iswolski [Cambridge: M.I.T. Press, 1963], 196-277), describes the fool of medieval popular culture in direct relation to Rabelais's work.

2. Sebastian Brant, The Ship of Fools, trans. Edwin H. Zeydel (1944; New York: Dover, 1962), 58 .

3. For further discussion of Erasmian irony in the Praise of Folly, see: Rosalie Colie, Paradoxia Epidemica (Princeton: Princeton University Press, 1966), 20; Jean-Claude Margolin, Érasme par lui-même (Paris: Seuil, 1967), 33-53 and Annette H. Tomarken, The Smile of Truth: The French Satirical Eulogy and Its Antecedents (Princeton: Princeton University Press, 1990), 28-48.

4. As André Gendre has argued, Foucault's assessment of Brant's humanist tendencies is not completely justified. See "Humanisme et folie chez Sébastien Brant, Érasme et Rabelais," Vorträge der Aeneas-Silvius-Stiftung an der Universität Basel, 14 (Basel: Helbing \& Lichtenhahn Verlag, 1978): 11.

5. Studies that have explored the notion of folly in Rabelais with particular attention to its relation to Erasmus include: André Gendre, "Humanisme et folie"; Walter Kaiser, Praisers of Folly: Erasmus, Rabelais, Shakespeare (Cambridge: Harvard University Press, 1963); Michael A. Screech, Rabelais (Ithaca: Cornell University Press, 1979) 260-81 and Ecstasy and the Praise of Folly (1980; London: Peregrine Books, 1988), 85.

6. The text of the letter is reproduced in François Rabelais, Oeuvres complètes, ed. Pierre Jourda, 2 vols. (Paris: Garnier, 1962), 2: 497-98. All further quotations of Rabelais's work are taken from this edition.

7. Desiderius Erasmus, The Praise of Folly, trans. John Wilson, 1688 (Ann Arbor: University of Michigan Press, 1969) 11, 56-57.

8. See Albert-Marie Schmidt, introduction to "Blasons du corps féminin," Poètes du XVI siècle, ed. Albert-Marie Schmidt (Paris: Gallimard, 1953), 293-4.

9. Cited in Schmidt, 294.

10. See his exhaustive study of the lists' formal and thematic interplay in Les Langages de Rabelais, Études Rabelaisiennes 10 (Genève: Droz, 1972), 162-72.

11. The blason is found in Oeuvres, 1:561-64. All subsequent quotations from the lists are taken from these pages. 
12. For a discussion of the heuristic value of analogy in the sixteenth-century, see Michel Foucault, Les mots et les choses (Paris: Gallimard, 1966), 32-59.

13. Only once does it seem that Pantagruel is inspired by Panurge: the giant's "souverain" follows Panurge's "soubarbade." But this may also be sheer coincidence, since "souverain" fully conforms to the theme set by the other items of Pantagruel's sequence, which includes: "redoubté," "transcendent," "special," "metaphysical," and "ecstaticque."

14. Early editions of Rabelais's works in the Bibliothèque Nationale reveal discrepancies in the printing history of the lists. Two unauthorized editions published in 1547, one in Lyons and the other in Valence, destroy the integrity of the two lists, randomly shifting Panurge's qualifiers to Pantagruel's list and vice-versa. But the Fezandat edition of 1552, which Rabelais corrected, presents the epithets in the same order and position as they appear in the Wechel edition of 1546 , whose printing Rabelais also probably oversaw. I thank Marian Rothstein for her help in documenting this note.

15. Wolfgang Iser, The Act of Reading (Baltimore: Johns Hopkins University Press, 1978), 35.

16. Wolfgang Iser, "The Reading Process: A Phenomenological Approach," Reader-Response Criticism, ed. Jane P. Tompkins (Baltimore: Johns Hopkins Unversity Press, 1980), 55. 